\title{
Sistem kontrol inventori pemasokan barang Secara Real Time Menggunakan Vendor-Managed Inventory (VMI) dan Short Message Service (SMS)
}

\author{
Rinaldo Turang ${ }^{\mathrm{a}}$, Djatmiko Endro Suseno ${ }^{\mathrm{b}}$ \\ ${ }^{a}$ Universitas Katolik De La Salle Manado \\ ${ }^{\mathrm{b} J u r u s a n}$ Fisika, Fakultas Sains dan Matematika Universitas Diponegoro
}

Naskah Diterima : 10 Mei 2014; Diterima Publikasi : 27 Juni 2014

\begin{abstract}
This research underlines the urgency of real-time stock replenishment control system for distributors using vendor-managed inventory. It is valuable in improving corporate performance in lowering inventory cost as well as making better customer service due to the cut made in ordering cycle. The system produces real-time information on stock available at the retailing stores. Stock replenishment can then be done by the distributor at the right time. Using Short Message Service (SMS) as a one-way information channel from retailers to their distributor, the data of every transaction of the supervised item are processed by a rule-based forward-chaining inference system to determine the item's availability in stores. Folowing steps in Rapid Application Development (RAD), the construction of this system takes place through business modeling, data modeling, process modeling of VMI system, then the application is generated and tested as a prototype. The results are: the stock replenishment control system are able to make transactional data at the stores transparent to the distributor, facilitating the continuation in stock delivery. System architecture reduces the time needed to access information about sales on supervised item by using SMS shortcut. This control system developed in stores can be operationally independent from the retailing systems. Rule-based forward-chaining inference technique processes facts on stock variations, resulting in stock replenishment notification such as normal, reserve, and depleted warning.
\end{abstract}

Keywords: VMI, inventory; Stock replenishment; Rule-based reasoning; Forward-chaining system, RAD

\begin{abstract}
Abstrak
Pada penelitian ini dibahas pengontrolan inventori pemasok yang menggunakan sistem Vendor-Managed Inventory (VMI). Sistem tersebut sangat bermanfaat untuk meningkatkan performa perusahaan dalam hal penurunan biaya inventori dan peningkatan tingkat pelayanan pelanggan oleh karena adanya pengurangan waktu siklus pemesanan. Sistem kontrol inventori pemasokan barang berguna untuk memberikan informasi real-time tentang posisi stok di setiap pengecer. Pembaharuan stok pun dapat dilakukan pada saat yang tepat. Penelitian ini menggunakan teknologi Short Message Service (SMS) sebagai media pengiriman data satu arah dari pengecer ke pemasok. Data penjualan diproses melalui penalaran berbasis aturan dengan metode forward-chaining untuk menentukan tingkat ketersediaan stok di setiap pengecer. Dengan menggunakan Rapid Application Development (RAD), aplikasi dikembangkan dengan memodelkan bisnis, data dan proses VMI, kemudian diimplementasi dalam bentuk prototipe. Hasil dari penelitian antara lain: sistem kontrol yang dibangun dapat melakukan transparansi data penjualan dan data stok kepada pemasok, sehingga pembaharuan stok secara berkelanjutan dan otomatis. Arsitektur sistem memperkecil waktu tunggu informasi, menggunakan jalur SMS sebagai jalan pintas distribusi data dari pengecer ke pemasok. Integrasi operasi yang dilakukan oleh pihak pemasok dan pengecer terlaksana secara mandiri, tanpa perlu melibatkan banyak kueri yang menghubungkan basis data yang berbeda-beda. Metode inferensi forward-chaining berbasis aturan yang diterapkan dapat mengolah fakta yang terjadi menyangkut perubahan stok di tingkat pengecer dan menghasilkan peringatan pembaharuan stok, berupa peringatan stok aman, cadangan dan awas.
\end{abstract}

Kata Kunci : VMI, inventori, pemasokan barang, penalaran berbasis aturan, forward-chaining, RAD

\section{Pendahuluan}

Proses bisnis yang dipraktekkan oleh suatu perusahaan senantiasa diarahkan kepada penciptaan nilai yang unik, kelebihan mana dapat diukur dengan uang. Dalam dunia retail secara khusus, mencuat segi bisnis properti. Bagian-bagian ruangan toko retail dan toko serba ada dipilah-pilah untuk menjadi area

\footnotetext{
*) Penulis korespondensi: t_turang@yahoo.com
}

bisnis dari berbagai produsen: ada toko di dalam toko. Penciptaan nilai sedemikian dikenal dengan vendor-managed inventory (VMI) yang telah dipopulerkan semenjak akhir 1980-an oleh Wal Mart, Procter dan Gamble dengan keuntungan yang signifikan (Cetinkaya et al., 2000), termasuk di dalamnya penurunan biaya inventori untuk pemasok dan pembeli (pengecer), dan peningkatan tingkat 
pelayanan pelanggan oleh karena adanya pengurangan waktu siklus pemesanan (Achabal et al., 2000 dan Waller et al., 1999). Sejalan dengan perkembangan teknologi di mana pertukaran informasi dapat terjadi semakin cepat dan semakin murah, kontrol inventori seperti ini berkembang pesat (Emigh, 1999).

VMI melakukan transparansi data penjualan dan level stok kepada pemasok, yang kemudian digunakan pemasok untuk mengatur inventori dengan lebih baik lewat pembaharuan stok secara berkelanjutan dan otomatis. Dalam sistem VMI, pemasok bertanggung jawab penuh untuk memelihara dan mengontrol inventori yang telah disepakati dengan pihak pengecer sebagai pembeli. Sistem ini menyederhanakan satu langkah dalam arus informasi rantai pasok. Informasi tentang kegiatan yang dilakukan oleh pembeli final pada pengecer segera dapat diketahui pemasok (Gronalt, 2008). Bentuknya yang paling sederhana adalah hanya dengan menggunakan spreadsheet dan surat elektronik (Disney et al., 2003).

Penggunaan Short Message Service (SMS) sebagai media pengumpulan data di lapangan telah menjadi alternatif yang layak dipertimbangkan. Penerapannya dalam membangun sistem pemantau data lapangan serta kontrol dari jarak jauh menunjukkan keunggulan dari segi biaya, cakupan area yang luas, dan kemudahan akses. Jarak dan waktu adalah dua aspek penting yang diperkecil dengan memanfaatkan teknologi ini.

Integrasi operasi yang dilakukan oleh pihak pemasok dan pengecer adalah krusial dalam membentuk sistem VMI. Oleh sebab itu, penelitian ini dilakukan dengan mempertimbangkan unsur realtime sebagai penghematan langkah yang signifikan, terutama pada arsitektur VMI dengan multicustomer. Ada beberapa kemungkinan yang bisa dipilih untuk mengusahakan integrasi ini. Pertama adalah dengan membuat suatu sistem informasi baru yang mengintegrasikan operasi di tingkat pengecer dan pemasok, kemungkinan mana menuntut usaha besar dan tekad yang kuat, mengingat variasi aplikasi dan basis data mandiri yang digunakan di banyak pengecer. Pun dalam suatu perusahaan pengecer yang sama, penerapan basis data yang terdistribusi menghambat perolehan informasi secara real-time. Kemungkinan kedua yang lebih sederhana adalah mengkompilasi lagi kode-kode program pada sistem yang berbeda-beda di tingkat pemasok dan pengecer setelah menambahkan obyek untuk mengotomasi pengiriman informasi data penjualan dan level stok. Kemungkinan ketiga adalah dengan mengembangkan sistem kontrol yang diletakkan di tingkat pengecer yang bersifat mandiri tanpa mempengaruhi aplikasi dan basis data yang sudah ada, yang dapat dioperasikan secara otomatis dan real-time. Karena efisiensi yang dapat diperoleh, kemungkinan yang terakhirlah yang menjadi pokok pembahasan dalam penelitian ini, dengan memanfaatkan teknologi SMS.

Berdasarkan permasalahan di atas, maka penelitian ini akan memecahkan bagaimana membangun sistem kontrol pemasokan barang menggunakan SMS pada VMI yang dapat diterapkan secara mandiri dan real-time, efisien dalam implementasi, dan efektif dalam meningkatkan performa perusahaan.

\section{KerangkaTeori}

\subsection{Vendor-Managed Inventory (VMI)}

VMI merupakan sistem inventori di mana pemasok memantau inventori kustomer dan membuat keputusan berkala tentang kapan dan seberapa banyak inventori harus diperbaharui. Dua keuntungan utama yang diperoleh adalah penurunan biaya dan peningkatan pelayanan (Waller et al., 1999).

Penerapan strategi dengan sistem VMI merupakan pendelegasian kontrol inventori kepada pemasok, termasuk pengirimannya. Integrasi yang terjadi lebih bersifat horisontal, di mana setiap pihak yang terlibat tetap memiliki otonomi masing-masing (Disney et al., 2003).

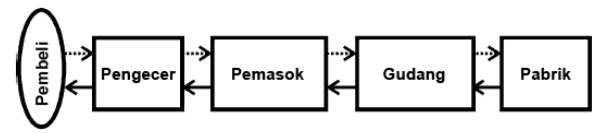

Gambar 1. Rantai pasok tradisional (Disney et al., 2003)

Rantai pasok tradisional pada Gambar 1 memiliki arus informasi yang mengalir sebagaimana ditunjukkan oleh garis putus-putus, dari pembeli menuju ke pengecer, pemasok, gudang, kemudian ke pabrik. Dalam rantai ini setiap pihak memperoleh informasi dari pihak yang mendahuluinya. Arus barang disalurkan dari pabrik menuju pembeli dalam urutan yang berlawanan, sebagaimana ditunjukkan oleh anak panah tegas.

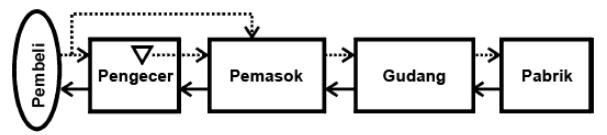

Gambar 2. Rantai pasok VMI (Disney et al., 2003)

Pada Gambar 2, rantai pasok VMI merupakan penyederhanaan langkah yang terjadi saat informasi dari pembeli langsung dapat diakses oleh pemasok. Dengan demikian umpan balik untuk menentukan kecepatan arus barang langsung dapat diambil sesuai kebutuhan.

Kontrol inventori pada sistem VMI bertujuan untuk mengatur stok di sisi pengecer. Dengan ditiadakannya fase pemesanan dari pengecer, pemasok bertanggung jawab untuk mengatur seluruh proses pengadaan kembali (Gronalt dan Rauch, 2008). Alur informasi, digambarkan dengan garis 
putus-putus pada Gambar 3, menunjukkan bagaimana sistem VMI mengawasi transaksi yang terjadi di pengecer. Pemesanan otomatis diproses berdasarkan masukan data penjualan dan level stok. Penyerahan barang dari pemasok diatur untuk menjamin ketersediaan barang bagi pembeli final.

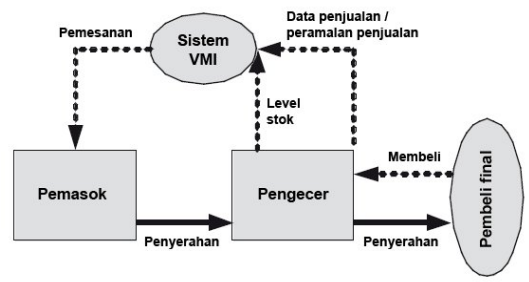

Gambar 3. Arus material dan informasi rantai pasok VMI (Gronalt dan Rauch, 2008)

\subsection{Reorder Point (Titik Pesan Kembali)}

Titik pesan kembali atau reorder point (ROP) didefinisikan sebagai jumlah terendah suatu barang yang tersedia sebelum melakukan pemesanan kembali.

ROP dapat dirumuskan sebagai berikut (Muller, 2003):

ROP $=($ Usage $x$ Lead Time $)+$ Safety Stock

Usage adalah kecepatan serap barang atau tingkat penjualan barang dalam suatu periode, lead time adalah waktu tunggu yang dibutuhkan untuk memperbaharui stok barang, safety stock adalah jumlah stok pengaman berkaitan dengan keterlambatan pembaharuan stok, dan ROP adalah titik pesan kembali. Safety stock dapat dirumuskan: $/ 2$

Safety Stock = Jumlah barang yang dijual pada waktu tunggu

\subsection{Metode Forward-Chaining}

Metode forward-chaining (Gambar 4) adalah strategi inferensi yang dimulai dengan sekumpulan fakta yang telah lebih dahulu diketahui, kemudian menurunkan fakta baru menggunakan aturan-aturan yang premisnya sesuai dengan fakta yang diketahui, selanjutnya melakukan perulangan proses ini sampai suatu tujuan tercapai atau sampai tidak ada lagi aturan yang premisnya sesuai dengan fakta yang diketahui atau fakta yang diturunkan (Durkin, 1994).

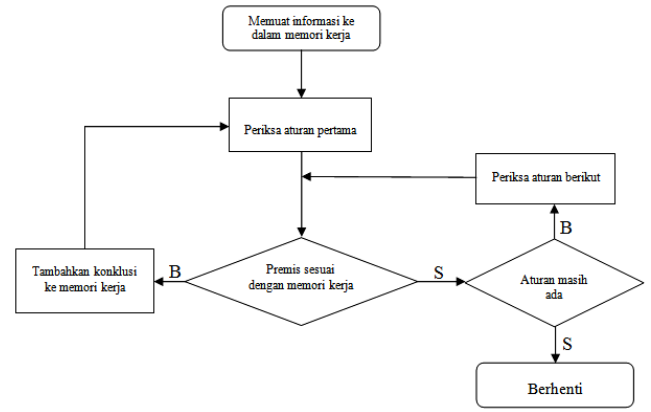

Gambar 4. Proses inferensi forward-chaining 2.4. Rapid Application Development (RAD)

Strategi RAD dalam pengembangan sistem menitikberatkan segi kecepatan pengembangan dengan keterlibatan besar dari pihak pengguna dalam konstruksi serangkaian prototipe sistem secara cepat, berulang-ulang dan bertahap, dan pada akhirnya mencapai bentuk sistem yang diinginkan (Whitten dan Bentley, 2007).

Tahapan yang ditempuh dalam mengembangkan sistem informasi menggunakan model RAD adalah sebagai berikut (Pressman, 2001):

a. Pemodelan bisnis, tahapan yang memodelkan arus informasi di dalam sistem untuk menjawab pertanyaan-pertanyaan seperti: Informasi apa yang akan dihasilkan? Siapa yang menjadi sumbernya? Ke mana informasi mengalir? Siapa yang mengolahnya?

b. Pemodelan data, yang mengelompokkan informasi yang mengalir ke dalam sistem ke dalam obyek-obyek lengkap dengan atributatributnya masing-masing dan kerelasian yang ada di antaranya.

c. Pemodelan proses, yang menggambarkan bagaimana obyek-obyek data diproses. Di dalamnya termasuk penambahan, pengubahan, penghapusan, atau pengambilan kembali obyek data.

d. Pembuatan aplikasi, yang memanfaatkan teknik generasi keempat dengan menggunakan kembali komponen-komponen yang telah ada. Aplikasi dibangun dengan bantuan kakas otomatis.

e. Pengujian dan penyerahan hasil.

\subsection{Sistem Barcode}

Pada awalnya simbol barcode dilambangkan dengan susunan paralel dari garis-garis vertikal dan spasi dengan kelebaran yang berbeda-beda. Bentuknya linear, atau satu dimensi. Dalam perkembangannya barcode dapat berbentuk matriks dengan dua dimensi, bahkan berbentuk tiga dimensi. Kode dicetak berdasarkan standar simbologi yang digunakan secara luas, sebagai contoh seperti UPC, Code 25, Code 128, EAN 8, dan EAN 13. Kode ini menggambarkan data dari obyek di atas mana barcode dicetak. Data yang direpresentasikan oleh barcode dibaca menggunakan pemindai barcode (Phaniteja dan Tom, 2013).

Keuntungan dari penerapan sistem barcode adalah menghemat waktu, mengurangi kesalahan, meningkatkan efisiensi operasional dan mengurangi biaya (Sharma et al., 2011). Sementara salah satu kelemahannya adalah kekeliruan pengoperasian oleh operator yang memandang sama beberapa barang yang kelihatan serupa (Phaniteja dan Tom, 2013).

\subsection{Short Message Service (SMS)}

SMS merupakan layanan standar komunikasi mobile antara pengirim dan penerima dengan melakukan dua hal: menyimpan pesan di sentra dan melanjutkan pesan kepada penerima. Karena pesan disimpan dulu, layanan ini tidak mengharuskan perangkat penerima aktif dan berada dalam 
jangkauan sinyal. Sentra yang menyimpan pesan hingga perangkat tujuan tersedia disebut SMS Centre (Katankar, 2010). Di kalangan pengguna korporat, layanan SMS dapat digunakan sebagai pemonitor jarak jauh yang memberikan informasi tentang keadaan alat tertentu atau terjadinya situasi tertentu (Bodic, 2005).

\section{Metodologi}

\subsection{Pemodelan Bisnis}

Pemodelan bisnis menggunakan penggambaran struktur sistem (Gambar 5) dan kerangka sistem (Gambar 6) yang akan dibangun. Struktur sistem menunjukkan pemodelan aliran data secara fisik dari pemindai barcode di tingkat pengecer yang kemudian ditransmisikan lewat SMS ke sistem pemasok.

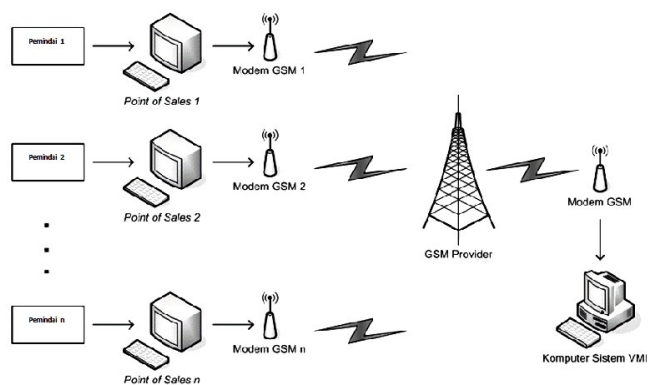

Gambar 5. Struktur sistem

Kerangka sistem menampilkan aliran data secara logis sebagai masukan, mengalami proses dan ditransformasikan menjadi informasi.

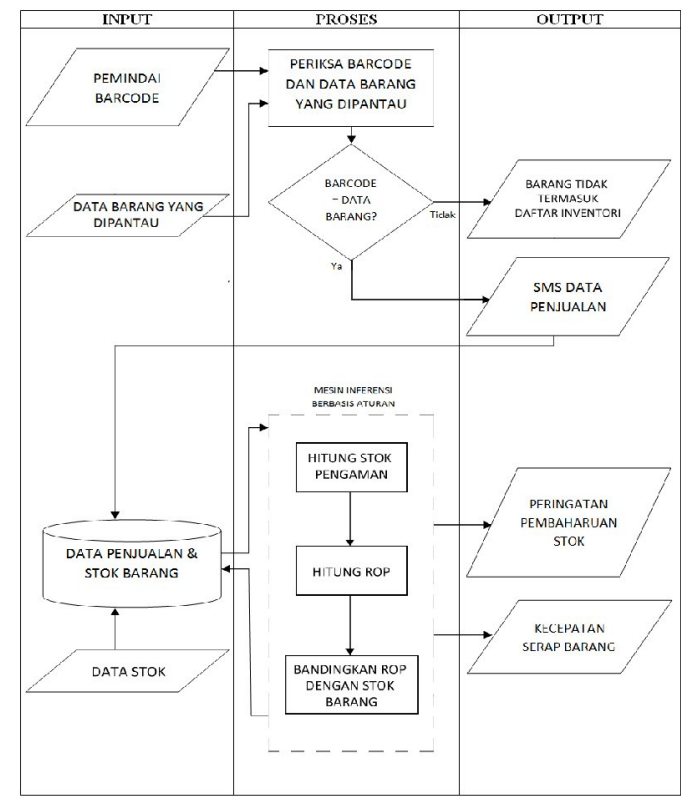

Gambar 6. Kerangka sistem

\subsection{Pemodelan Data}

Penggambaran pemodelan data dilakukan dengan ERD untuk melihat hubungan antara obyek-obyek data yang terlibat dalam sistem (Gambar 7).

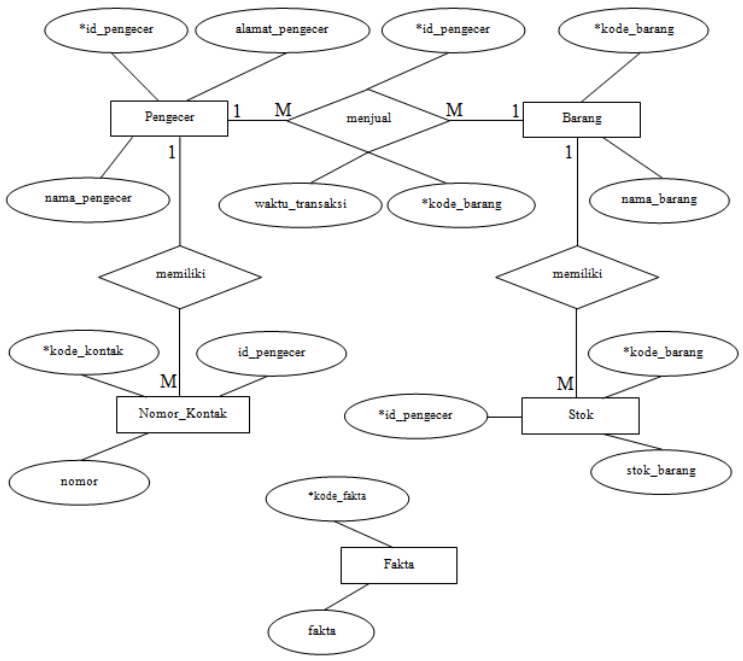

Gambar 7. ERD sistem kontrol inventori pada VMI

\subsection{Pemodelan Proses}

Proses dimodelkan menggunakan DFD (Gambar 8). Diagram level-nol menggambarkan sistem secara keseluruhan beserta aliran data sebagai masukan dan keluaran dalam kaitan dengan entitas luar.

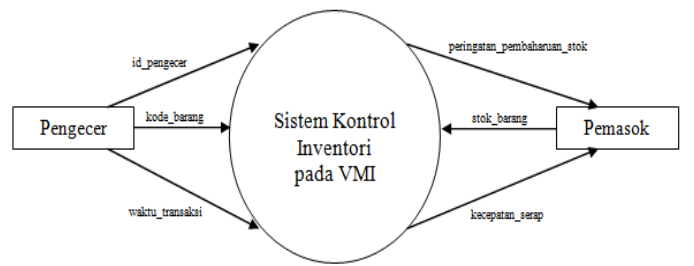

Gambar 8. Diagram level-nol sistem

Sistem kontrol inventori dipecah menjadi tiga proses utama. Gambar 9 menampilkan diagram levelsatu yang menunjukkan proses-proses yang terjadi dalam sistem kontrol inventori pada VMI dengan tiga proses utama:

a. Proses penyimpanan data penjualan (Gambar 10), yang dipecah menjadi dua. Proses pertama menyimpan data penjualan yang terjadi di setiap pengecer berhubungan dengan barang yang dipantau. Proses kedua mengubah posisi stok pada tabel stok.

b. Proses pengecekan pembaharuan stok (Gambar 11), yang juga dipecah menjadi dua. Proses pertama dimaksudkan untuk menentukan stok pengaman dan titik pesan kembali berdasarkan rumus tentang ROP. Sedangkan proses kedua menjalankan mesin inferensi berbasis aturan untuk mengecek apakah pembaharuan stok perlu dilakukan. 
c. Proses perhitungan kecepatan serap barang.

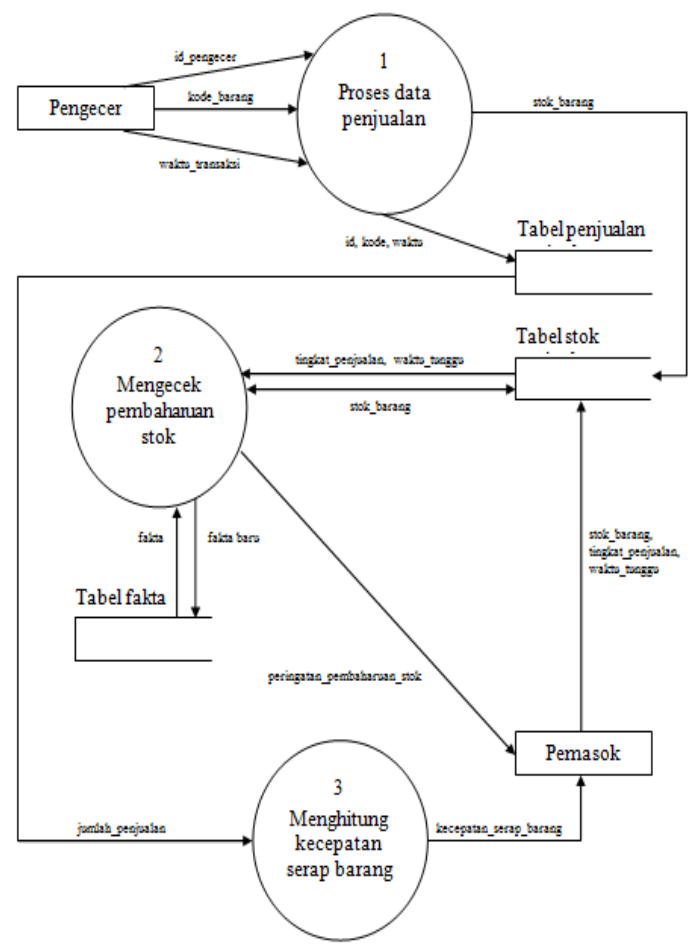

Gambar 9. Diagram level-satu sistem

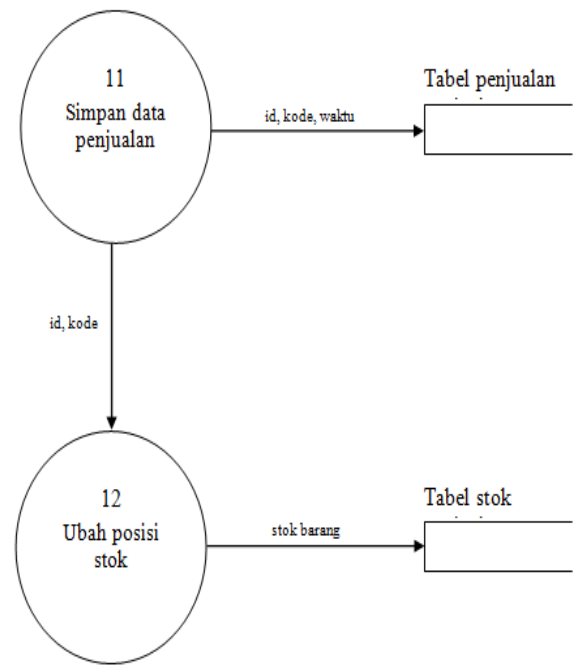

Gambar 10. Diagram level-dua proses 1: Proses data penjualan

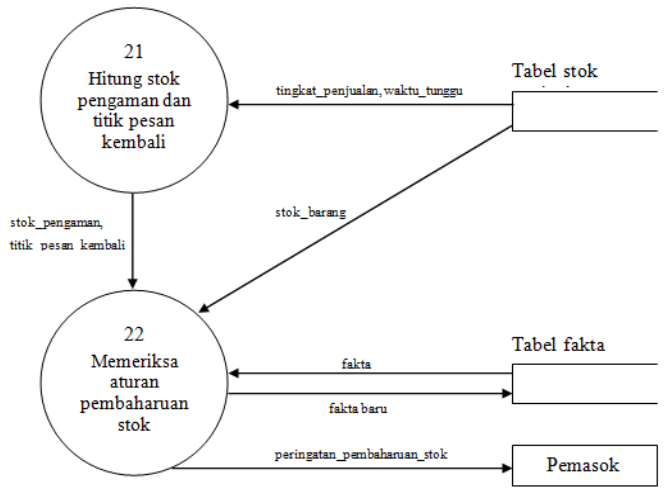

Gambar 11. Diagram level-dua proses 2: Mengecek pembaharuan stok

Aturan-aturan inferensi Forward-Chaining berdasarkan pemodelan proses yang telah dilakukan, selanjutnya ditetapkan aturan-aturan inferensi yang menggunakan stok barang, stok cadangan, stok pengaman, titik pesan kembali, dan jumlah penjualan sebagai variabel, seperti ditunjukkan pada Tabel 3.1.

Tabel 1. Aturan-aturan peringatan pembaharuan stok

\begin{tabular}{ll}
\hline No & \multicolumn{1}{c}{ Aturan } \\
\hline R1 & $\begin{array}{l}\text { IF stok barang }>=\text { ROP } \\
\text { THEN status stok }=\text { aman }\end{array}$ \\
R2 & $\begin{array}{l}\text { IF stok barang }<\text { ROP } \\
\text { THEN stok cadangan }\end{array}$ \\
R3 & $\begin{array}{l}\text { IF stok cadangan } \\
\text { AND stok barang }<\text { stok pengaman } \\
\end{array}$ \\
THEN status stok = awas \\
R4 & IF stok cadangan \\
& THEN status stok = cadangan \\
R5 & IF status stok = aman \\
& THEN peringatan stok normal \\
R6 & IF status stok = cadangan \\
& THEN peringatan stok cadangan \\
R7 & IF status stok = awas \\
& THEN peringatan stok awas \\
\hline
\end{tabular}

\section{Hasil dan Pembahasan}

\subsection{Masukan}

Data yang menjadi masukan sistem adalah data penjualan yang menentukan posisi stok barang pada pengecer. Data ini berupa data barang yang dipantau, tanggal transaksi dan pengecer yang melakukan transaksi. Ketiga data ini diperoleh setiap kali terjadi transaksi di kasir. Untuk mendapatkan data tersebut, aplikasi didesain untuk melakukan pengecekan lewat fungsi key logging untuk mendapatkan transaksi yang berkaitan dengan barang yang dipantau. Data barang diperoleh dengan mencocokkan kode barang waktu transaksi dengan kode barang yang dipantau. Jika cocok, aplikasi akan mengirimkan SMS berisi kode ke nomor kontak sistem pada pemasok. Tanggal transaksi diperoleh dari tanggal pengiriman SMS. 
Data pengecer didapatkan dengan mencocokkan nomor pengirim dengan registrasi nomor kontak pengecer. Tampilan masukan data penjualan ditunjukkan pada Gambar 12. Karena dirancang untuk bekerja di latar belakang, bagian aplikasi untuk menangkap data penjualan ini berjalan dalam modus diperkecil, akan tetapi dapat diperbesar untuk melakukan penyesuaian yang dibutuhkan menyangkut kode barang yang dipantau dan nomor kontak pemasok yang akan dikirimi SMS.

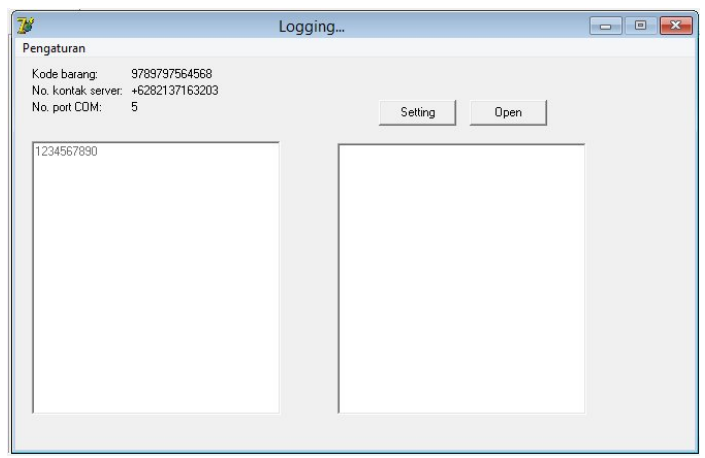

Gambar 12. Tampilan masukan data penjualan

\subsection{Proses Data Penjualan}

Tampilan form terima SMS seperti pada Gambar 13 melakukan proses data penjualan yang dibagi menjadi dua proses turunan. Pertama, proses simpan data penjualan menyeleksi SMS yang masuk sesuai dengan data nomor kontak pengecer, kemudian menyimpan data yang memenuhi syarat ke dalam tabel penjualan pada basis data. Kedua, proses ubah posisi stok mengurangi stok pengecer yang bersangkutan dalam tabel stok.

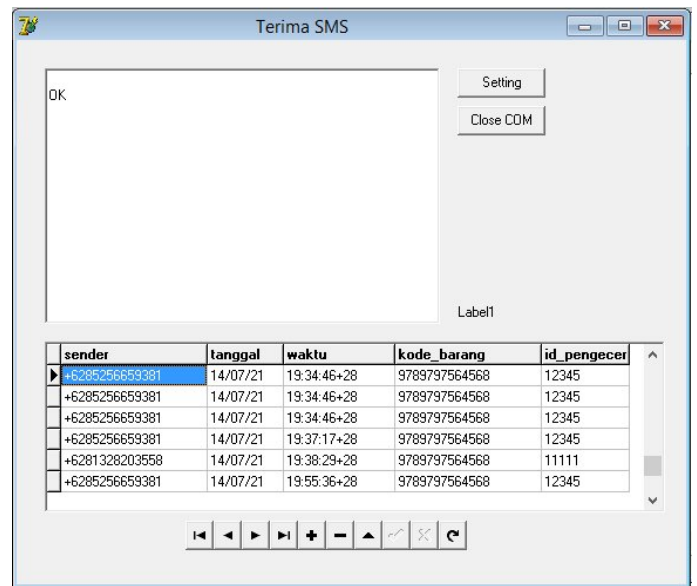

Gambar 13. Tampilan proses simpan data penjualan

\subsection{Mengecek Pembaharuan Stok}

Sebelum memberikan peringatan pembaharuan stok, sistem melakukan pengecekan pembaharuan stok dalam dua langkah yang dilakukan dalam selang yang telah ditentukan. Langkah pertama, proses menghitung stok pengaman dan titik pesan kembali, menerapkan rumus untuk menghitung ROP sebagaimana ditampilkan dalam penggalan kode pada Gambar 14. Setelah diketahui jumlah stok pengaman dan titik pesan kembali, langkah berikutnya dilakukan untuk memeriksa aturan pembaharuan stok. Aturan-aturan yang terpicu sebagaimana ditampilkan pada Gambar 15 mengubah fakta yang disimpan dalam tabel fakta.
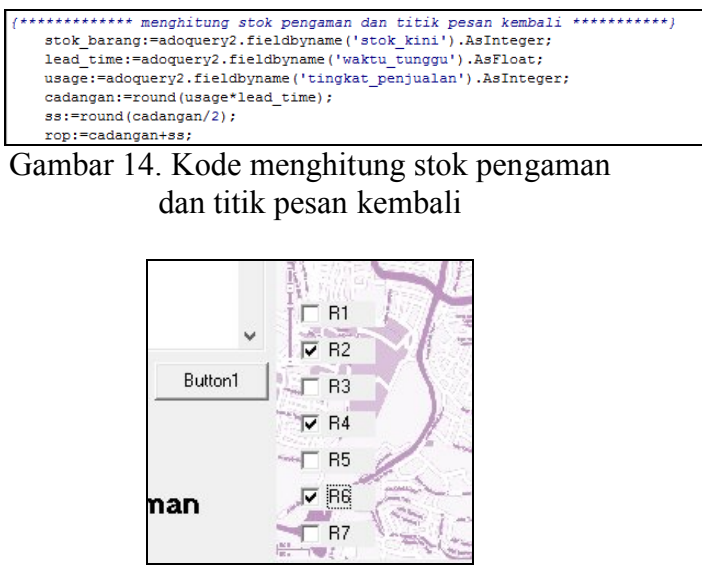

Gambar 15. Proses inferensi berbasis aturan

\subsection{Menghitung Kecepatan Serap Barang (Usage)}

Kecepatan serap barang dihitung dalam kurun waktu bulanan dengan cara mengumpulkan transaksi yang terjadi pada bulan yang bersangkutan sebagaimana disimpan dalam tabel penjualan. Gambar 16 menunjukkan penggalan kode untuk melakukan proses penghitungan kecepatan serap barang dengan cara melakukan kueri pada tabel penjualan dan tabel pengecer. Kecepatan serap barang inilah yang digunakan sebagai tingkat penjualan barang atau usage.

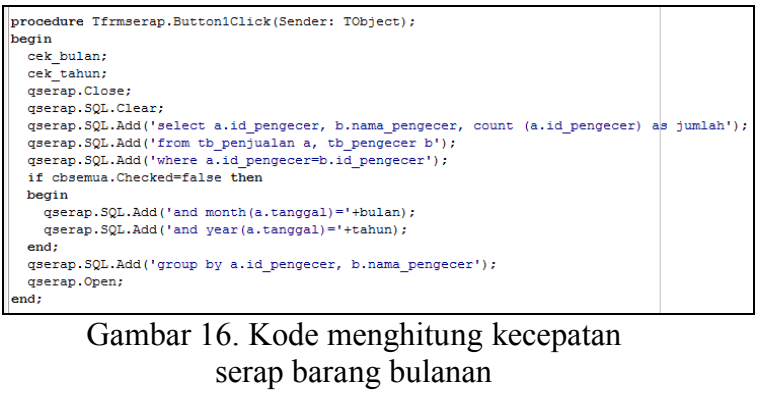

\subsection{Keluaran}

Informasi yang diperoleh dari sistem ini adalah peringatan pembaharuan stok. Dari proses inferensi untuk membandingkan posisi stok dengan titik pesan kembali, ditampilkan posisi stok real time setiap pengecer sambil memberikan peringatan dalam bentuk tampilan grafis seperti Gambar 17. Warna hijau digunakan untuk menunjukkan posisi stok aman, warna kuning untuk pengecer yang harus 
dibaharui stoknya dan warna merah untuk pengecer yang sedang menggunakan stok pengaman. Informasi ini dihasilkan sesuai dengan selang waktu yang ditetapkan.

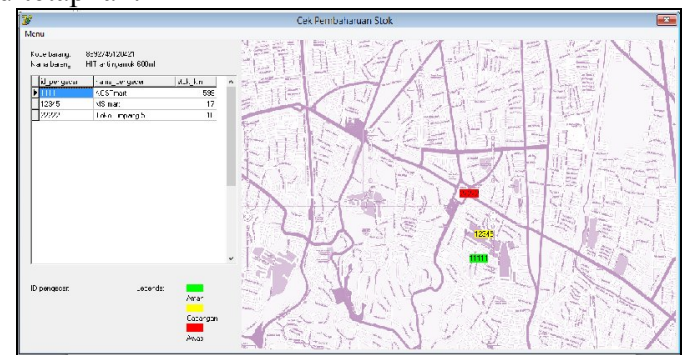

Gambar 17. Tampilan posisi stok secara real-time

Selanjutnya saat diminta pengguna, sistem menghasilkan informasi tentang kecepatan serap barang pada setiap pengecer dan menampilkan hasilnya dalam bentuk tampilan pada Gambar 18 . Informasi ini dijadikan acuan pengecer untuk menetapkan tingkat penjualan barang.

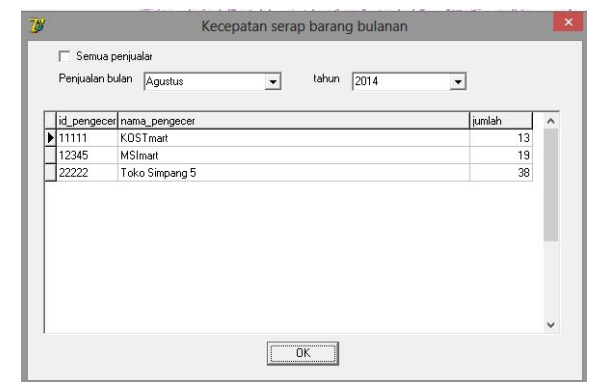

Gambar 18. Informasi kecepatan serap barang bulanan

Keluaran sistem kontrol pemasokan barang berupa peringatan pembaharuan stok merupakan hasil inferensi yang dilakukan terhadap fakta yang dialami pada saat terjadi perubahan stok. Sesuai dengan aturan-aturan yang telah ditetapkan, fakta diolah untuk mendapatkan kesimpulan menyangkut ketersediaan stok di tingkat pengecer yang dibedakan atas tiga tingkatan: aman, cadangan dan awas. Pada saat status stok menyentuh cadangan, pemasok harus segera memproses pengiriman untuk memperbaharui stok pengecer. Situasi di tingkat pengecer selalu berada dalam pantauan sistem sebagaimana ditunjukkan pada Gambar 19.

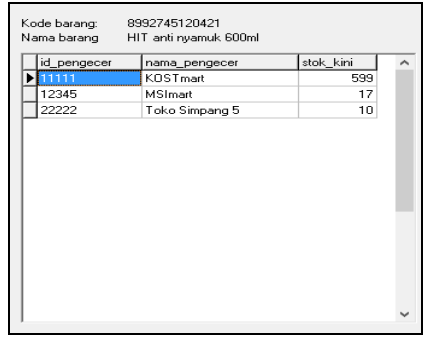

Gambar 19. Posisi stok real-time di tingkat pengecer

\subsection{Simulasi Peringatan Stok Normal}

Diberikan suatu situasi untuk menggambarkan keadaan persediaan aman. Stok kini berjumlah 86 , tingkat penjualan 60 barang per bulan, waktu tunggu untuk pembaharuan stok memerlukan 2 minggu, atau 0,5 dalam persentase bulanan.

Untuk menentukan stok pengaman atau safety stock, digunakan rumus: 12

Safety Stock = Jumlah barang yang dijual pada waktu tunggu

Safety Stock $=(60 \times 0.5) / 2$

Safety Stock $=30 / 2$

Safety Stock $=15$

Maka ROP dapat dihitung sebagai berikut.

$R O P=($ Usage $x$ Lead Time $)+$ Safety Stock

$R O P=(60 \times 0.5)+$ Safety Stock

$R O P=30+15$

$R O P=45$

Mesin inferensi membandingkan ROP sebesar 45 dengan stok kini sebesar 86. Karena stok kini lebih besar dari ROP, aturan R1 dan R5 pada mesin inferensi akan terpicu sebagaimana ditampilkan pada Gambar 4.9, sehingga fakta yang terekam dalam basis data seperti pada Gambar 20 menunjukkan bahwa stok berada dalam keadaan normal.

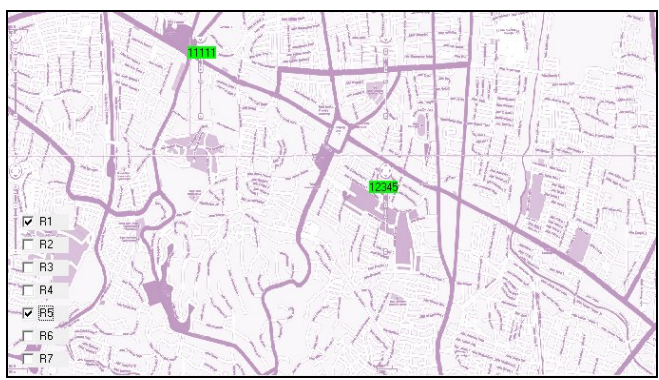

Gambar 20. Aturan yang terpicu untuk peringatan status stok aman

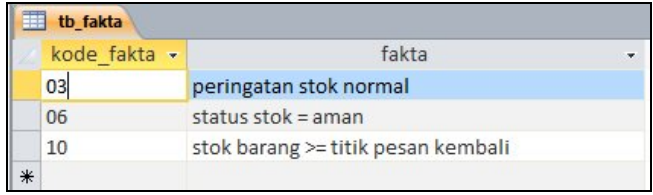

Gambar 21. Fakta peringatan stok normal

\subsection{Simulasi Peringatan Stok Cadangan}

Diberikan suatu situasi untuk menggambarkan keadaan persediaan cadangan. Stok kini berjumlah 20 , tingkat penjualan 80 barang per bulan, waktu tunggu untuk pembaharuan stok memerlukan 1 minggu, atau 0,25 dalam persentase bulanan.

Untuk menentukan stok pengaman atau safety stock, digunakan rumus:

Safety Stock = Jumlah barang yang dijual pada waktu tunggu $/ 2$ Safety Stock $=(80 \times 0.25) / 2$

Safety Stock $=20 / 2$

Safety Stock $=10$

Maka ROP dapat dihitung sebagai berikut.

$R O P=($ Usage $x$ Lead Time $)+$ Safety Stock

$R O P=(80 \times 0.25)+$ Safety Stock

$R O P=20+10$

$R O P=30$ 
Karena stok kini lebih kecil dari ROP tetapi lebih besar dari safety stock, Gambar 22 menunjukkan terpicunya aturan R2, R4 dan R6, dan menyebabkan fakta-fakta seperti pada Gambar 4.12 tersimpan ke dalam basis data. Hasilnya, peringatan stok cadangan akan diberikan sebagai pemberitahuan untuk segera membaharui stok.

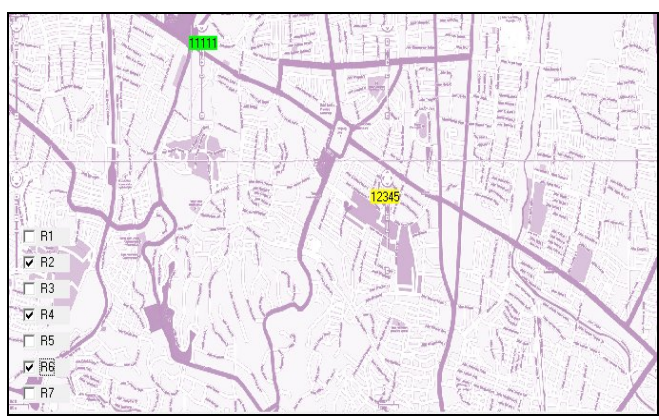

Gambar 22. Aturan yang terpicu untuk peringatan status stok cadangan

\begin{tabular}{|ll|}
\hline $\begin{array}{l}\text { to_fakta } \\
\text { kode_fakta }\end{array}$ & \multicolumn{1}{c|}{ fakta } \\
\hline 02 & peringatan stok cadangan \\
\hline 04 & status stok = cadangan \\
07 & stok cadangan \\
09 & stok barang < titik pesan kembali \\
\hline * & \\
\hline
\end{tabular}

Gambar 23. Fakta peringatan stok cadangan

\subsection{Simulasi Peringatan Stok Awas}

Diberikan suatu situasi untuk menggambarkan keadaan persediaan awas. Stok kini berjumlah 10 , tingkat penjualan 88 barang per bulan, waktu tunggu untuk pembaharuan stok memerlukan 1 minggu, atau 0,25 dalam persentase bulanan.

Untuk menentukan stok pengaman atau safety stock, digunakan rumus: 12

Safety Stock = Jumlah barang yang dijual pada waktu tunggu

Safety Stock $=(88 \times 0.25) / 2$

Safety Stock $=22 / 2$

Safety Stock $=11$

Maka ROP dapat dihitung sebagai berikut.

$R O P=($ Usage $x$ Lead Time $)+$ Safety Stock

$R O P=(88 \times 0.25)+$ Safety Stock

$R O P=22+11$

$R O P=33$

Posisi stok menunjukkan jumlah yang lebih kecil dari safety stock. Ini berarti stok pengaman sudah mulai digunakan. Aturan yang terpicu sebagaimana ditunjukkan pada Gambar 24 adalah R2, R3 dan R7. Dari fakta pada basis data seperti Gambar 25 disimpulkan bahwa stok dalam keadaan awas. Bila pengiriman belum juga diproses maka dapat dipastikan akan terjadi kehabisan stok.

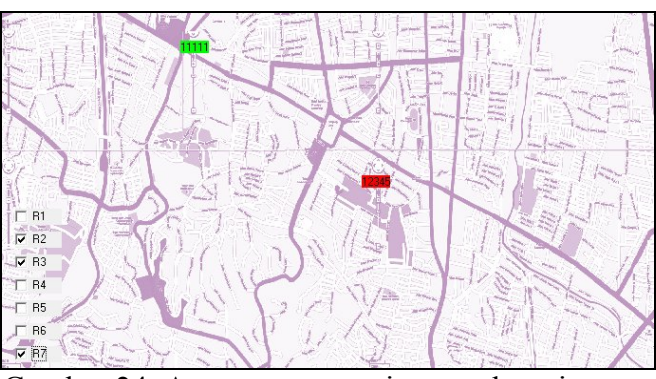

Gambar 24. Aturan yang terpicu untuk peringatan status stok awas

\begin{tabular}{||ll|}
\hline \begin{tabular}{|l|} 
to_fakta \\
kode_fakta
\end{tabular} & \multicolumn{1}{c|}{ fakta } \\
\hline 01 & peringatan stok awas \\
\hline 05 & status stok = awas \\
07 & stok cadangan \\
08 & stok barang < stok pengaman \\
\hline 09 & stok barang < titik pesan kembali \\
\hline * & \\
\hline
\end{tabular}

Gambar 25. Fakta peringatan stok awas

Ketiga kemungkinan yang dapat terjadi digambarkan secara grafis pada keluaran sistem kontrol pemasokan barang ini. Gambar 26 menunjukkan penggunaan warna merah, kuning dan hijau. Pembedaan warna untuk menampilkan informasi tentang ketersediaan stok dimaksudkan untuk memberikan peringatan. Hijau menggambarkan situasi normal. Saat tampilan berubah kuning, stok cadangan sudah mulai digunakan, dan pemasok harus segera memperbaharui stok pengecer. Warna merah menunjukkan akan terjadinya kehabisan stok.

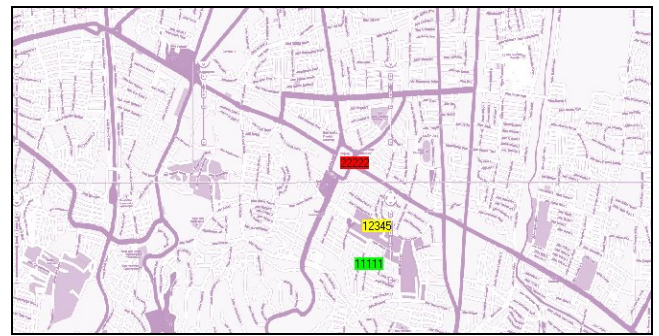

Gambar 26. Pembedaan warna untuk menampilkan peringatan

\section{Kesimpulan}

Sistem yang diteliti telah melewati fase pemodelan bisnis, pemodelan data, pemodelan proses, dan diimplementasikan sesuai dengan tahapan penelitian. Beberapa pokok penting yang dapat disimpulkan pada penelitian ini adalah:

1. Sistem kontrol inventori pemasokan barang yang dihasilkan ini sejalan dengan tujuan penelitian untuk melakukan pemantauan secara real time tentang posisi stok, titik pemesanan kembali, dan peninjauan periodik tentang kecepatan serap 
barang pada pemasok menggunakan VMI dan SMS.

2. Sistem kontrol yang diterapkan di tingkat pengecer dapat terintegrasi secara mandiri.

3. Metode inferensi forward-chaining berbasis aturan yang diterapkan dapat mengolah fakta yang terjadi menyangkut perubahan stok di tingkat pengecer dan menghasilkan peringatan pembaharuan stok yang dibedakan menjadi peringatan stok aman, stok cadangan dan stok awas.

\section{Daftar Pustaka}

Achabal, D. Mclntyre, S., Smith S., Kalyanam, K., 2000. A decision support system for vendor managed inventory. Journal of Retailing, 76 (4), $430-454$.

Bodic, G. L., 2005. Mobile Messaging Technologies and Services SMS, EMS and MMS, John Wiley \& Son Ltd.

Cetinkaya, S., Lee, C.Y., 2000. Stock replenishment and shipment scheduling for vendor-managed inventory systems. Management Science, 46 (2), 217-232.

Disney, S.M., Potter, A.T., Gardner, B.M., 2003, The impact of vendor managed inventory on transport operations. Transportation Research Part E 39, 363-380.
Durkin, J., 1994. Expert System: Design and Development, New York : McMilan Publishing.

Emigh, J., 1999, Vendor-Managed Inventory, Computerworld 33 (34), 52.

Gronalt, M., Rauch, P., 2008. vendor managed inventory in wood processing industries -a case study. Silva Fennica 42 (1), 101-114.

Katankar, V.K., Thakare, V.M., 2010. Short message service using sms gateway. International Journal on Computer Science and Engineering 2 (4), 1487-1491.

Muller, M., 2003. Essentials of Inventory Managements, Amacom.

Phaniteja, J., Tom, P.D.J., 2013. Evolution of barcode. International Journal for Development of Computer Science and Technology 1 (2).

Pressman, R.S., 2001. Software Engineering: A Practitioner's Approach, McGraw-Hill.

Sharma, D., Sharma, V., Shrivastava, B., Songara, R. K., Sharma, P., 2011. regulatory aspect of barcode technology. Asian Journal of Pharmaceutical Sciences And Research, 1(4).

Waller, M., Johnson, M.E., Davis, T., 1999. Vendormanaged inventory in the retail supply chain. Journal of Business Logistics 20 (1), 183-203.

Whitten, J.L., Bentley, L.D., 2007. Systems Analysis and Design Methods, McGraw-Hill/Irwin. 